\title{
Changes in crop canopy architecture on the incidence of major foliar diseases of betelvine (Piper betle L.)
}

\author{
Basudeb Dasgupta* and Solanki Sarkar \\ Department of Plant Pathology, Bidhan Chandra Krishi Viswavidyalaya, Mohanpur, Nadia, 741252, West Bengal, India. \\ *E-mail: dasgupta.basudeb824@gmail.com
}

\begin{abstract}
Betelvine (Piper betle L.) is a perennial dioecious creeper-belonging to the family Piperaceae usually grown under artificially erected structurals known as baroj that provides high moist and humid conditions favouring several diseases that in turn are major deterrents to good harvest. Betelvine suffers from many root and aerial diseases of which leaf rot caused by Phytophthora parasitica (Dastur) and leaf spot caused by Colletotrichum capsici Syd. (Butler and Bisby) are most important and are included in these studies for assessment. The extent of losses may vary from $20-40 \%$ for leaf rot and $10-20 \%$ for leaf spot, leading to almost total crop failure (Dasgupta and Sen, 1999). As the betel leaf is directly chewed immediately after harvest, it is not feasible to apply any pesticides that may cause toxic hazards to human being. An experiment was conducted for two consecutive years (2013 and 2014) to study the effect of different crop canopy by maintaining three different plant to plant spacing (viz. $11.1 \mathrm{~cm} .9 .53 \mathrm{~cm}$. and $8.3 \mathrm{~cm}$.) on leaf yield, disease incidence and keeping quality (days to $50 \%$ rotting) of betelvine. With the above plant to plant spacing and standard row to row spacing (60 $\mathrm{cm}$ ), the plant population was maintained as $1.50,1.75$ and 2.00 lakh ha ${ }^{-1}$. The results revealed that when crop canopy was increased by reducing the plant to plant spacing from $11.1 \mathrm{~cm}$ to $8.3 \mathrm{~cm}$ there were significant increases in both the diseases under investigation (rot disease $19.76 \%$ to $22.30 \%$; leaf spot disease $22.68 \%$ to $25.42 \%$ ). Significant increase in yield (26.29 to 33.63 lakh ha $\left.^{-1} \mathrm{year}^{-1}\right)$, decrease in fresh weight of 100 leaves (460.85g to $432.35 \mathrm{~g}$ ) and decrease in keeping quality of leaves (13.14 days to 10.28 days) were recorded when crop canopy was increased by reduction in plant to plant spacing from $11.1 \mathrm{~cm}$ to $8.3 \mathrm{~cm}$. From these results it can be concluded that shifts in microclimate resulting from increase in canopy by reducing the plant spacing aggravated the spread and infection of disease.
\end{abstract}

Key words: Crop canopy, betelvine, Phytophthora parasitica, Colletotrichum capsici

\section{Introduction}

Betelvine is grown under artificially erected structurals known as 'baroj' or 'bareja' or 'bheet' made up bamboo poles, sticks, khari, jute sticks, paddy straw, ulu straw or coconut, arecanut leaves that provide highly moist and humid conditions favouring good harvest. However, these conditions also favour several diseases that detrimentally affect the growth and yield parameters. Betelvine suffers from many root and aerial diseases of which leaf rot caused by Phytophthora parasitica (Dastur) and leaf spot caused by Colletotrichum capsici Syd. (Butler and Bisby) are most important. The extent of losses may vary from $20-40 \%$ in case of leaf rot and 10-20\% incase of leaf spot, leading to almost total crop failure (Dasgupta and Sen, 1999).

There is a large volume of literature available for the management of leaf rot caused by Phytophthora parasitica (Dastur) and leaf spot caused by Colletotrichum capsici Syd. (Butler and Bisby) with chemicals starting from the early works of pioneers like Dastur, 1931, '35; McRae, '34; Hector,'30; Chowdhury,'44 to present day. These have been recorded from time to time (Chattopadhyay 1967; Saxena, 1977; Sen et al., 1981; Khare et al., 1988; Dasgupta et al., 1988; Chattopadhyay and Maiti, 1990; Dasgupta '93; Dasgupta and Sen, '96; Maiti and Shivshankar, 1998; Dasgupta and Sen, 1999 and Dasgupta et al., 2000) and the consensus that emerges is that no efficient method of controlling the above two diseases of betelvine are available yet i.e., effective as well as safe. Moreover, a tiny amount of pesticide carried by the leaf would be hazardous to human health due to the residual toxicity of the pesticide as they are non-biodegradable and as the leaves are chewed directly, immediately after harvest (Bhattacharya et al., 1988; 1989 and 1992; Guha et al., 1990; Kar et al.,1995). Moreover microclimate inside the baroj favours plant diseases which depend upon the canopy structure of the baroj. Farmers are growing betelvine in rows on ridge with different plant to plant spacing (viz. $11.1 \mathrm{~cm} .9 .53 \mathrm{~cm}$. and $8.3 \mathrm{~cm}$.) and standard row to row spacing $(60 \mathrm{~cm})$. With the above plant to plant spacing and standard row to row spacing $(60 \mathrm{~cm})$, the plant population was maintained as $1.50,1.75$ and 2.00 lakh ha $^{-1}$. The present investigations were carried out to study the effect of different crop canopy (by maintaining three different plant to plant spacing) on leaf yield, disease incidence and keeping quality (days to $50 \%$ rotting) of betelvine.

\section{Materials and methods}

The experiment was carried out in a randomized block design with seven replications in a boroj situated at Plant Virus Research Farm, Kalyani, Bidhan Chandra Krishi Viswavidyalaya soil of the plot was sandy loam alluvial soil (Entisol) with $\mathrm{pH}$ 7.4 and having $0.54 \%$ organic carbon, $0.06 \%$ total $\mathrm{N}, 55 \mathrm{~kg}$ ha $^{-1}$ of available $\mathrm{P}_{2} \mathrm{O}_{5}$ and $100 \mathrm{~kg} \mathrm{ha}^{-1}$ of $\mathrm{K}_{2} \mathrm{O}$ respectively. The experiment was conducted within the month of first week of July to last week of October, for two consecutive years i.e. 2013 and 2014. The variety of crop was Simurali Bhabna. The treatments for the experiment were as follows: 


\begin{tabular}{|c|c|c|}
\hline \multirow[t]{2}{*}{ Treatments details } & \multicolumn{2}{|c|}{ Spacing between } \\
\hline & Row & Plant \\
\hline $\mathrm{T}_{1}=1.50$ lakh ha $^{-1}$ plant population & $60 \mathrm{~cm}$ & $11.1 \mathrm{~cm}$ \\
\hline $\mathrm{T}_{2}=1.75$ lakh ha ${ }^{-1}$ plant population & $60 \mathrm{~cm}$ & $9.53 \mathrm{~cm}$ \\
\hline $\mathrm{T}_{3}^{2}=2.00$ lakh $\mathrm{ha}^{-1}$ plant population & $60 \mathrm{~cm}$ & $8.3 \mathrm{~cm}$ \\
\hline
\end{tabular}

The crop was fertilized @ $200 \mathrm{~kg} \mathrm{~N}$ in the form of (MOC+Urea $1: 1$ ) in four equal splits at an interval of 30 days, $100 \mathrm{~kg} \mathrm{P}_{2} \mathrm{O}_{5}$ as single super phosphate and $100 \mathrm{~kg} \mathrm{~K}_{2} \mathrm{O}$ as muriate of Potash ha-1 year-1 $\mathrm{P}_{2} \mathrm{O}_{5}$ and $\mathrm{K}_{2} \mathrm{O}$ were applied along with first application of nitrogenous fertilizer i.e. at the onset of monsoon.

Before conducting the experiment all the infected leaves and diseased plants in treatment rows were removed. The vine elongations, fresh weight of 100 leaves, leaf yield, keeping quality, percent disease incidence were recorded. The percent disease incidence was calculated by the formula (Townsend and HeuBerger, 1943) as follows:

$$
\text { Percent disease incidence }=\frac{\text { Number of infected leaves }}{\text { Total number of leaves }} \times 100
$$

\section{Results and discussion}

Vine elongation month ${ }^{-1}$ (cm): The results (Table-1) showed that the maximum and minimum vine elongation per month was recorded in $\mathrm{T}_{3}$ treatment $\left(57.99 \mathrm{~cm} \mathrm{month}^{-1}\right)$ and $\mathrm{T}_{1}$ treatment $\left(53.22 \mathrm{~cm} \mathrm{month}^{-1}\right)$ respectively in 2013. In 2014, the maximum and minimum vine elongation per month was recorded in $\mathrm{T}_{2}$ treatment $\left(57.82 \mathrm{~cm} \mathrm{month}^{-1}\right)$ and in $\mathrm{T}_{3}$ treatment $(52.07 \mathrm{~cm}$ month $^{-1}$ ) respectively. In Pooled analysis of two years data revealed that the maximum and minimum vine elongation per month was recorded in $\mathrm{T}_{2}$ treatment $\left(55.85 \mathrm{~cm} \mathrm{month}^{-1}\right)$ and in $\mathrm{T}_{1}$ treatment $\left(53.45 \mathrm{~cm} \mathrm{month}^{-1}\right)$ respectively.

The results of vine elongation month ${ }^{-1}(\mathrm{~cm})$ with regard to results of different spacing treatments were showed in the following order: $\mathrm{T}_{2}, \mathrm{~T}_{3}>\mathrm{T}_{1}$ (Pooled).

The result therefore indicated that vine elongation was increased with increasing plant population or decreasing plant spacing. These results confirmed the observations of AICRP on betelvine reports that vine elongation increased with increase in the plant population from 1.5 to 2.0 lakh (Anonymous, 2001-02).

Fresh weight of 100 leaves (g): Maximum fresh weight of 100 leaves was recorded in $\mathrm{T}_{2}$ treatment $(418.57,460.85 \mathrm{~g}$ ) respectively where 1.75 lakh ha $^{-1}$ plant population was maintained and it was found statistically superior to all the other treatments in the year 2013 and pooled analysis of two years data. In 2014 the maximum fresh weight of 100 leaves was recorded in $\mathrm{T}_{3}$ treatment (522.71 g) where 2.00 lakh ha ${ }^{-1}$ plant population was maintained and it was statistically superior to all the other treatments. The minimum fresh weight of 100 leaves was recorded in $\mathrm{T}_{3}$ treatment (360.71 g) where a 2.00 lakh ha $^{-1}$ plant population was maintained in the year 2013. In 2014 the minimum fresh weight of 100 leaves was recorded in $\mathrm{T}_{1}$ treatment $(495.71 \mathrm{~g})$. The pooled analysis of two years data revealed that the minimum fresh weight of 100 leaves was recorded in $\mathrm{T}_{1}$ treatment (432.35 g) (Table 1).

These results of fresh weight of 100 leaves $(\mathrm{g})$ may be arranged in the following order: $\mathrm{T}_{2}>\mathrm{T}_{3}, \mathrm{~T}_{1}$ (Pooled).

Different plant spacings $(11.1 \mathrm{~cm}, 9.53 \mathrm{~cm}$ and $8.3 \mathrm{~cm})$ were also reflected on fresh weight of 100 leaves $(\mathrm{g})$ and their differences were statistically significant in both the years and also in pooled mean. The result contradicts with the result obtained in the experiment of AICRP on betelvine in the year 2001-02 that fresh weight of 100 leaves parameter was statistically not significant with the plant spacing (Anonymous, 2001-02).

Effect of spacings on leaf yield (lakh ha-1 year $^{-1}$ ) of betelvine: Maximum leaf yield was recorded in $\mathrm{T}_{2}$ treatment $(31.17,33.63$ lakh ha ${ }^{-1}$ year ${ }^{-1}$ respectively) where 1.75 lakh ha $^{-1}$ plant population was maintained in the year 2013 and pooled analysis of two years data (Table 1). Treatment $\mathrm{T}_{3}$, where 2.00 lakh ha $^{-1}$ plant population was maintained recorded maximum leaf yield (37.03 lakh ha-1 year $\left.^{-1}\right)$ in the year 2014. The minimum leaf yield $(20.04,32.55$

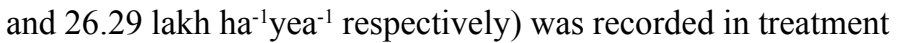
$\mathrm{T}_{1}$ where 1.50 lakh $\mathrm{ha}^{-1}$ plant population $(11.1 \mathrm{~cm}$ spacing) was maintained.

The results of the leaf yield (lakh ha-1 year ${ }^{-1}$ ) in different treatments showed a decreasing order like: $\mathrm{T}_{2}>\mathrm{T}_{3}>\mathrm{T}_{1}$ (Pooled).

These results thus revealed that different plant spacings showed differential result in leaf yield (lakh ha ${ }^{-1}$ year $^{-1}$ ) in two different years and also in pooled mean and their differences were statistically significant. Similar result was also obtained by Pawar et al. (2006) that highest leaf yield was obtained from $50 \times 10$ $\mathrm{cm}$ spacings, the minimum spacing kept in their experiments. It indicated that with decreasing spacing there was a significant increase in leaf yield though $9.53 \mathrm{~cm}$ spacing gave better results.

Effect of spacing on keeping quality (days to $50 \%$ rotting) of betelvine: Keeping quality was best in $\mathrm{T}_{1}$ and $\mathrm{T}_{2}$ treatments $(10.28$ days) and the poor keeping quality was recorded in treatment $\mathrm{T}_{3}$ (9.00 days) in 2013. In 2014 the maximum keeping quality was recorded in $\mathrm{T}_{3}$ treatment (15.28 days) and minimum keeping quality was recorded in $\mathrm{T}_{2}$ treatment (12.28 days). The pooled analysis data of two years revealed that the maximum keeping quality was recorded also in $\mathrm{T}_{3}$ (12.14 days) and minimum keeping quality was also in treatment $\mathrm{T}_{2}$ (11.28 days) (Table 1$)$.

The results of two different years showed different results in keeping quality of betelvine leaves in different plant spacing. Table 1. Effect of Crop canopy structure on growth, Fresh weight, Yield and Keeping quality of Betelvine

\begin{tabular}{|c|c|c|c|c|c|c|c|c|c|c|c|c|}
\hline \multirow{2}{*}{$\begin{array}{l}\text { Treatments } \\
\text { (plant } \\
\text { population) }\end{array}$} & \multicolumn{3}{|c|}{$\begin{array}{l}\text { Vine elongation } \text { Month }^{-1} \\
(\mathrm{~cm})\end{array}$} & \multicolumn{3}{|c|}{$\begin{array}{c}\text { Fresh weight of } \\
100 \text { leaves }(\mathrm{g})\end{array}$} & \multicolumn{3}{|c|}{$\begin{array}{c}\text { Leaf yield }^{1} \\
\left(\text { Lakh ha }^{-1} \text { year }\right)\end{array}$} & \multicolumn{3}{|c|}{$\begin{array}{c}\text { Keeping quality } \\
\text { (days to } 50 \% \text { rotting) }\end{array}$} \\
\hline & $2013^{1}$ & $2014^{1}$ & Pooled & $2013^{1}$ & $2014^{1}$ & Pooled & $2013^{1}$ & $2014^{1}$ & Pooled & $2013^{1}$ & $2014^{1}$ & Pooled \\
\hline 1.50 lakh ha-1 & 53.22 & 53.67 & 53.45 & 369.00 & 495.71 & 432.35 & 20.04 & 32.55 & 26.29 & 10.28 & 13.00 & 11.64 \\
\hline 1.75 lakh ha-1 $^{-1}$ & 53.88 & 57.82 & 55.85 & 418.57 & 503.14 & 460.85 & 31.17 & 36.08 & 33.63 & 10.28 & 12.28 & 11.28 \\
\hline 2.00 lakh ha $^{-1}$ & 57.99 & 52.07 & 55.03 & 360.71 & 522.71 & 441.71 & 24.85 & 37.03 & 30.94 & 9.00 & 15.28 & 12.14 \\
\hline $\operatorname{SEm}( \pm)$ & 0.67 & 0.63 & 0.36 & 4.32 & 4.63 & 3.28 & 0.96 & 1.09 & 0.78 & 0.81 & 0.78 & 0.62 \\
\hline $\operatorname{LSD}(P=0.05)$ & 2.05 & 1.94 & 1.10 & 13.30 & 14.27 & 10.12 & 2.95 & 3.36 & 2.41 & NS & 2.40 & NS \\
\hline
\end{tabular}

${ }^{1}$ Average of seven replications 
Table 2. Effect of Crop canopy structure on disease incidence of Betelvine

\begin{tabular}{|c|c|c|c|c|c|c|}
\hline \multirow{2}{*}{$\begin{array}{l}\text { Treatments } \\
\text { (plant population) }\end{array}$} & \multicolumn{3}{|c|}{ Leaf spot : C.O.Colletotrichum capsici } & \multicolumn{3}{|c|}{ Leaf rot: C.O. Phytophthora spp. } \\
\hline & $2013^{1}$ & $2014^{1}$ & Pooled & $2013^{1}$ & $2014^{1}$ & Pooled \\
\hline 1.50 lakh ha $^{-1}$ & $16.27(23.72)^{*}$ & $11.48(21.45)$ & $14.90(22.68)$ & $13.92(21.87)$ & $9.10(17.28)$ & $11.51(19.76)$ \\
\hline 1.75 lakh ha h $^{-1}$ & $16.84(24.15)$ & $13.45(21.20)$ & $15.15(22.80)$ & $17.50(24.69)$ & 9.84(17.99) & $13.67(21.68)$ \\
\hline 2.00 lakh ha-1 $^{-1}$ & $16.76(24.09)$ & $20.21(26.62)$ & $18.48(25.42)$ & $14.39(22.26)$ & $14.47(22.31)$ & $14.43(22.30)$ \\
\hline $\operatorname{SEm}( \pm)$ & 0.67 & 1.34 & 0.62 & 0.57 & 1.26 & 0.57 \\
\hline $\operatorname{LSD}(P=0.05)$ & NS & 4.14 & 1.91 & 1.74 & 3.87 & 1.74 \\
\hline
\end{tabular}

${ }^{1}$ Average of seven replications.

*Figures in parenthesis represent angular transformed values.

This result also confirms the result of AICRP on betelvine in the year 2000-01 (Anonymous, 2000-01).

\section{Effect of plant spacing on disease incidence (\%) of betelvine}

Leaf spot (C. O. Colletotrichum capsici): Minimum leaf spot due to Colletotrichum capsici $(16.27 \%)$ was recorded in treatment $\mathrm{T}_{1}$ and maximum in $\mathrm{T}_{2}$ treatment $(16.84 \%)$ in 2013 . In 2014 the minimum leaf spot disease $(11.48 \%$ ) was recorded in $\mathrm{T}_{1}$ treatment and the maximum leaf spot was recorded in the treatment $\mathrm{T}_{3}(20.21 \%)$ (Table 2$)$. The pooled analysis of two years data revealed that the minimum leaf spot disease was recorded in treatment $\mathrm{T}_{1}(14.90 \%)$ and the maximum leaf spot was recorded in the treatment $\mathrm{T}_{3}(18.48 \%)$.

It was noticed that leaf spot disease incidence increased with decrease of plant spacing. This may be due to microclimate developed in minimum spacing helped in spread and infection of diseases.

These results of leaf spot disease (C.O. Colletotrichum capsici) of betelvine at different plant spacing showed the following order like: $\mathrm{T}_{3}>\mathrm{T}_{2}, \mathrm{~T}_{1}$ (Pooled).

Leaf rot (C. O. Phytophthora spp.): The minimum leaf rot disease (Table 2) was recorded in $\mathrm{T}_{1}$ treatment $(13.92 \%)$ in 2013. In 2014 the minimum leaf rot disease was recorded in the above $\mathrm{T}_{1}$ treatment $(9.10 \%)$. Pooled analysis of two years data revealed that the minimum leaf rot disease was recorded in treatment $\mathrm{T}_{1}(11.51 \%)$. The maximum leaf rot disease was recorded in treatment $\mathrm{T}_{2}(17.50 \%)$ in 2013. In 2014 the maximum leaf rot disease was recorded in treatment $T_{3}(14.47 \%)$. In pooled analysis of two years data revealed that the maximum leaf rot disease was recorded in treatment $\mathrm{T}_{3}(14.43 \%)$ (Table 2$)$.

The results of leaf rot disease (C.O. Phytophthora spp) of betelvine at different plant spacing showed the results of the following order like: $\mathrm{T}_{3}, \mathrm{~T}_{2}>\mathrm{T}_{1}$ (Pooled).

The results revealed that leaf rot disease caused by Phytophthora spp showed different disease reaction in different plant spacing and their differences were statistically significant. With decreasing plant spacing there was a significant increase in disease incidence. It indicated that with increasing plant spacing there was a significant decrease in leaf rot of betelvine. The result also confirmed the result of Pawar et al. (2006) that minimum plant spacing harbour the leaf rot disease incidence.

From these results it was concluded that a change in microclimate occurred due to a change in plant canopy. By increasing the plant spacing, growth and yield of Betelvine was not increased but incidence of disease is reduced due to changes in micro-climate within the plant canopy.

Correlations between microclimate and incidence of diseases should be made before giving final recommendation to the farmers. However, these results give some information about the effect of plant canopy architecture on disease incidence, growth and yield of betelvine.

\section{References}

Anonymous. 2000-01. Proc. All India Coordinated Research Project on Betelvine, NRC for MAP, Boriavi, Anand, Gujrat, P. 137.

Anonymous. 2001-02. Proc. All India Coordinated Research Project on Betelvine, NRC for MAP, Boriavi, Anand, Gujrat, P. 152.

Bhattacharya, Anjan, A.Chowdhury, A.K.Das, B.Dasgupta and K.Sengupta, 1988. Studies on the foltaf residue in betelvine leaves. Tropical Pest Management, 34(2): 154-55.

Bhattacharyya, Anjan, P.Bera, A.K.Das, A.Chowdhury, B.Dasgupta and K.Sengupta 1989. Studies on carbendazim residues occurring in betelvine leaves. Pesticides, 23(2): 41-43.

Bhattacharya, Anjan., Asit Kr. Das and B.Dasgupta, 1992. Studies on the persistence of Carbofuran residues in betelvine. Pestology, 16(11): 14-17.

Chattopadhyay, S.B. 1967. Diseases of plant yielding Drugs, Dyes and Spices, ICAR, New Delhi.

Chattopadhyay, S.B. and S. Maity, 1990. Diseases of betelvine and spices, New Delhi, Indian Council of Agricultural Research (ICAR), pp. 160.

Chowdhury, S. 1944. Diseases of 'Pan' (Piper betle L.) in Seylet, Assam, Assam-II. Phytophthora foot rot and leaf rot. Proc. Indian Acad. Sci. Section-B. 19 : 152-164.

Dasgupta, B., K. Sengupta and S. Karmakar, 1988. Chemical control of foliage diseases of betelvine. Indian Agriculturist, 32(2): 99-105.

Dasgupta, B. 1993. Chemical control of root rot and leaf rot of betelvine caused by Phytophthora palmivora using Bordeaux mixture. In : Current Trends in Life Sciences, Vol. 19. Recent Trends in Plant Disease Control (Eds. H. B. Singh, D. N. Upadhyay and L. R. Saha), pp. 75-88. Today and Tomorrow Printers in Publishers, New Delhi.

Dasgupta, B and C.Sen,1999. Assessment of Phytophthora root rot of betelvine and its management using chemicals. J. Mycol. Plant, Pathol, 29:91-95.

Dasgupta, B. and C. Sen, 1996. Loss assessment and use of chemicals in the management of Phytophthora root rot of betelvine. Indian J. Mycol. Plant Pathol., 26 : 37-39.

Dasgupta, B., J.K. Roy, and C. Sen, 2000. Two major fungal diseases of betelvine. In Diseases of Plantation Crops, Spices, Betelvine and Mulberry (Ed. M. K. Dasgupta), pp. 133-137.

Dastur, J.F. 1931. A short note on foot rot diseases of pan (Piper betel L.) in the central provinces. Agric. J. India, 22 : 105-108.

Dastur, J.F. 1935. Diseases of Pan (Piper betle) in the Central Provinces. Proc. Indian Acad. Sci., 1(11) : 26-31.

Guha, P.K., P. Halder, B.Dasgupta, K. Sengupta and Anjan Bhattacharya, 1990. Studies on the dissipation of Carbendazim residues in/on betelvine leaves. Pestology, 24(11): 23-26.

Hector, G.P. 1930. Annual Report of the first Economic Botanist to the Government of Bengal for the year 1930-31. Ann Rep. Dep. Of Agric. Bengal for the year 1930-31, pp. 35-44. 
Khare, M.N., M.S. Bhale, D.P. Tiwari, and M.L. Nayak, 1988. Current status of Phytopathora foot and leaf rot of betelvine. Perspectives in Mycology and Plant Pathology, 168-177.

Kar, N. Satya, Subir K. Nag, S.Pal, B.Dasgupta and N. Adityachaudhury, 1995. persistence of copper on betelvine (Piper betle L) leaves and soil following application of Bordeaux mixture. Pesticide Research Journal, 8(1): 71-74.

Maiti, S. and K.C. Shivashankara, 1998. Betelvine Research Highlights (1981-1997), ICAR, AICRP on Betelvine, IIHR, Bangalore.

McRae, W. 1934. Foot rot diseases of Piper betle L. in Bengal. Indian J. Agric. Sci., 4 : 585-617.

Pawar, V.P., M.S.Shirke, S.M.Magdum and B.M.Kamble, 2006. Response of betelvine (Piper betle L.) to different planting densities and spacing. Ind. J. of Arecanut; Spices and Medicinal Plants. 8 (1):10-12.
Saksena, S.B. 1977. Phytophthora parasitica, the scourge of 'Pan'. Indian Phytopathology, $30: 1-16$.

Sen, C., S.Maiti, and D.C. Khatua, 1981. Control of rot and foot rot diseases of betelvine caused by fungal pathogens. Proceedings Improvement of Betelvine Cultivation, NBRI, Lucknow, Feb. 2728, pp. 33.

Townsend, G.R. and J.W.Heuberger, 1943. Methods for estimating losses caused by disease in fungicidal treatment. Plant Dis. Reptr., 27:340-42. 